\title{
Forbedret fosterdiagnostikk?
}

Universitetssykehuset Nord-Norge har søkt Helsedirektoratet om å ta i bruk en ikke-invasiv prenatal diagnostisk test (NIPD). Ved hjelp av den kan man finne cellefritt føtalt DNA i gravide kvinners blod og lete etter kromosomavvik. Metoden er tenkt å erstatte dagens prosedyrer, som er tidlig ultralydundersøkelse og blodprøve av kvinner over 38 år. De fleste som får et høyt riskotall etter en slik screening, velger i tillegg invasive tester (fostervannsprøve eller chorionbiopsi). I dag får også et stort antall kvinner under 38 år ultralydundersøkelse og blodprøve (1).

Flere studier viser at de nye prøvene har langt høyere sensitivitet og spesifisitet for trisomi 21, 13 og 18 enn dagens screeningtester i høyrisikopopulasjoner (2). Dessuten kan man med mer nøyaktige metoder slippe å bekrefte diagnosen via risikofylte invasive tester, slik man må i dag. Den nye testen kan tas tidlig i svangerskapet (før grensen for selvbestemt abort), slik at belastningene for kvinnen kan reduseres. Den kan brukes til rhesustesting og til å fastslå fosterets kjønn med stor grad av sikkerhet.

Som et ledd i sin behandling av søknaden har Helsedirektoratet bedt Bioteknologinemnda om en uttalelse. Den gamle nemnda rakk kun en foreløpig behandling og uttalte at «det er umulig å si nei til en metode som synes å være mer treffsikker og har mindre risiko, og som attpåtil er kostnadseffektiv» (3). Vi er her inne i en utvikling som er umulig å stoppe, hevder fremtredende norske medisinetikere $(3,4)$.

Vi har altså en ny test som er mer nøyaktig, innebærer lavere risiko og er mer kostnadseffektiv enn de eksisterende - og som det er umulig å stanse. Likevel nøler myndighetene og ber Kunnskapssenteret om en full kunnskapsoppsummering (5). Hvorfor?

For det første reises det spørsmål om nøyaktigheten av ikke-invasiv prenatal diagnostikk til bruk i screening. Testens spesifisitet og sensitivitet skriver seg fra studier av grupper med høy forekomst av aneuploidi, ikke fra den reelle målgruppen (2). Vi mangler også kunnskap om sannsynligheten for at et positivt testresultat predikerer en sann aneuploidi (positiv prediktiv verdi). Dette har gjort at flere av de store fagsammenslutningene, slik som the American Congress of Obstetricians and Gynecologists, the Society for Maternal-Fetal Medicine og the National Society of Genetic Counselors, har anbefalt at man gjør invasive tester i tillegg (2). Men da reduserer testen ikke risikoen, slik som forespeilt.

For det andre gir den nye testen en rekke andre muligheter som man også må ta stilling til. Den muliggjør tidlig kjønnsbestemmelse med stor nøyaktighet (6), og studier viser at det er mulig å gjøre helgenomsekvensering av fosteret (7-10). I fremtiden kan man derfor trolig fastslå en lang rekke genetiske egenskaper hos fosteret på et tidlig tidspunkt - før grensen for selvbestemt abort. Å åpne for fritt fravalg av fostre bryter med idealene om et åpent og inkluderende samfunn, men det å begrense individets selvbestemmelse ut ifra fellesskapsidealer er en utfordrende øvelse.

For det tredje er det vanskelig å sette grenser for ikke-invasiv prenatal testing. Å spesifisere hvilke tilstander det kan testes for, øker faren for å stemple personer med slike tilstander. Når disse tilhører sterkere grupper (fordi man tillater testing for mindre alvorlige tilstander), tiltar beskyldninger om manglende respekt, nedvurdering og diskriminering. Vi vil få mer eksplisitte og høylytte uttalelser om at grupper i samfunnet er «utryddingstruet». Å tillate tester for enkelte egenskaper (trisomi 21), men ikke for andre (kjønn, klumpfot, polydaktyli) krever begrunnelse. Vi må kunne forklare at de som har tilstander som vi systematisk søker å finne og fjerne, har samme verdi som alle andre. Det er ikke enkelt.

Argumentet om at vi bør si ja til testen nå fordi «det blir umulig å si nei», forutsetter at vi er maktesløse lakeier. På den annen side argumenterer andre for at vi ikke må tillate det første steg (som er akseptabelt) fordi det da blir umulig å si nei til neste steg (som vi ikke liker). Det første argumentet kalles «det automatiske fremskrittsargumentet», det siste «skråplansargumentet». Mens tilhengerne bruker det automatiske fremskrittsargumentet til å fremme utviklingen, bruker kritikerne skråplansargumentet for å bremse eller stanse den. Problemet er at begge argumentene er tvilsomme (11). Vi trenger grundigere drøftinger enn dette.

Det står derfor mer på spill enn bare å erstatte en test med en nyere og bedre. Vi står overfor et faglig og moralsk skifte der vi må klargjøre noen vesentlige skiller: mellom svangerskapsomsorg og fosterdiagnostikk, mellom tilfeldig testing og systematisk fravalg og mellom å fornærme og å diskriminere funksjonshemmede. Vi må eksplisitt si hvilke tilstander vi ikke ønsker i samfunnet og hvorfor - og vi må klargjøre hva vi mener med «et samfunn der det er plass til alle».

\section{Bjørn Hofmann}

b.m.hofmann@medisin.uio.no

Bjørn Hofmann (f. 1964) er professor i medisinsk etikk ved Høgskolen i Gjøvik og ved Universitetet i Oslo. Han forsker og underviser i medisinsk etikk, vitenskapsteori, teknologiteori og medisinsk metodevurdering. Forfatter har fylt ut ICMJE-skjemaet og oppgir ingen interessekonflikter.

\section{Litteratur}

1. Røe K, Salvesen KÅ, Eggebø TM. Blir retningslinjene for fosterdiagnostisk ultralyd fulgt? Tidsskr Nor Legeforen 2012; 132: $1603-6$.

2. Morain S, Greene MF, Mello MM. A new era in noninvasive prenatal testing N Engl J Med 2013; 369: 499-501.

3. Skogstrøm L. Ny fostertest til vurdering: påviser Downs syndrom i 9. uke. Aftenposten 14.8.2013.

4. NTB. Flertall sier ja til Downs-blodprøve. Aftenposten 29.7.2013. www.aftenposten.no/familie-og-oppvekst/Flertall-sier-ja-til-Downs-blodprove7266139.html (2.10.2013)

5. Helsedirektoratet. De første oppdragene til metodevurdering. http://helsedirektoratet.no/Om/nyheter/Sider/bestillinger.aspx (2.10.2013)

6. Wright CF, Wei Y, Higgins JP et al. Non-invasive prenatal diagnostic test accuracy for fetal sex using cell-free DNA a review and meta-analysis. BMC Res Notes 2012: 5: 476

7. Fan HC, Gu W, Wang J et al. Non-invasive prenatal measurement of the fetal genome. Nature 2012; 487: 320-4

8. Lo YM, Chan KC, Sun $\mathrm{H}$ et al. Maternal plasma DNA sequencing reveals the genome-wide genetic and mutational profile of the fetus. Sci Transl Med 2010; 2: 61 ra91

9. Kitzman JO, Snyder MW, Ventura M et al. Noninvasive whole-genome sequenc ing of a human fetus. Sci Transl Med 2012; 4: 137ra76.

10. Papageorgiou EA, Patsalis PC. Maternal plasma sequencing: a powerful tool towards fetal whole genome recovery. BMC Med 2013; 11: 56.

11. Holm S, Takala T. High hopes and automatic escalators: a critique of some new arguments in bioethics. J Med Ethics 2007; 33: 1-4 